\title{
Vertebrobasilar Strokes in Children
}

\author{
A. Al Tawaria R.A. Ouvrier ${ }^{\text {b }} \quad$ A.W. Steinberg ${ }^{\text {c }}$ P. Grattan-Smith ${ }^{\text {b }}$ \\ A. Antony ${ }^{b}$ \\ aNeurology Unit, Chidren's Department, Al Sabah Hospital, Kuwait, Departments of \\ ${ }^{b}$ Neurology and 'Radiology, The New Children's Hospital, Sydney, Australia
}

\author{
Key Words \\ Vertebrobasilar stroke · Complication . \\ Children
}

\begin{abstract}
Objectives: This study describes the rare disorder of vertebrobasilar strokes in children and provides an assessment strategy to alert the clinician towards the possibility of this disorder. Method: A retrospective study of vertebrobasilar strokes over 20 years was conducted in the Neurology Department at the New Children's Hospital, Sydney, Australia. Results: There were 6 males and 3 females between the ages of 18 months and 15 years. Frequently presenting features included headache, hemiparesis, ataxia and cranial nerve palsies. Aphasia occurred in 2 and afebrile seizures in 1 patient. Five patients had depressed consciousness extending to coma in 3. Etiological factors included trauma to the head or neck in 5, rheumatic
\end{abstract}

\begin{tabular}{ll}
\hline KARGER & (1) 1998 S. Karger AG, Basel \\
Fax +4161306 1234 & $1011-7571 / 00 / 0093-0186 \$ 17.50 / 0$ \\
$\begin{array}{l}\text { E-Mail karger@karger.ch } \\
\text { www.karger.com }\end{array}$ & $\begin{array}{l}\text { Accessible online at: } \\
\text { www.karger.com/journals/mpp }\end{array}$
\end{tabular}

endocarditis with artificial valve embolism in 1 , brain stem encephalitis in 1 and undetermined etiology in 2. Diagnostic neuroimaging studies including MRI showed infarction in the territories of the occluded arteries. MRA showed occlusion of the vertebral artery and/or its branches in 5 patients, while the other 4 patients had involvement of the basilar artery and/or its branches. No abnormalities of blood coagulation were detected. Five patients were treated with anticoagulants. Acute hydrocephalus secondary to cerebellar infarction developed in 3 patients. Recurrent vertebrobasilar strokes were reported in 2 males, each of whom was treated surgically. There was 1 late death. Residual neurological deficits were seen in 5 patients and 3 made a complete recovery. Conclusion: Although this disorder is rare in pediatric patients, it is important to consider it in those children with appropriate neurological symptoms and signs.

\footnotetext{
Copyright $(\subset 2001$ S. Karger AG, Basel
}

Asma A. Al Tawari

bdullah Salem 72252 (Kuwait)

E-Mail atawari@kma.org.kw 


\section{Introduction}

Cerebrovascular strokes are well recognized in adults, but not in children. With the advent of better diagnostic tests, it has become evident that this disorder is not so rare in children. There are several case reports [15] and a few series [6-8] of vertebrobasilar disease published in the literature. Garg et al. described 6 children with posterior cerebral artery branch infarct [6] and 3 boys with strokes following vertebral artery trauma [7]. Ouvrier and Hopkins [8] reported 3 cases of occlusive disease in the vertebrobasilar system.

Several disorders may involve the basilar and vertebral arteries and disrupt the blood flow to the brain stem and cerebellum [9]. Episodes of headache, hemiparesis, ataxia and disturbance of consciousness, speech and vision can manifest with these disorders. In this series of children with vertebrobasilar occlusive disease, the objectives of the study were to identify the clinical syndromes resulting from these strokes, the etiologies, neuroimaging appearance including correlation of magnetic resonance imaging (MRI) and angiographic findings, complications and eventual outcome.

\section{Patients and Methods}

The medical records of patients admitted to the New Children's Hospital, Westmead, with stroke over the 20-year period from 1978 to 1998 were identified. Of the 31 cases with cerebrovascular accidents, 9 patients with vertebrobasilar insufficiency were selected. They ranged in age from 18 months to 15 years, and were reviewed for clinical and radiological features, etiology, complications, treatment and outcome (table 1). Radiological examinations included computerized tomography (CT) for all patients, MRI in 7, magnetic resonance angiography (MRA) in 3 and conventional angiography in 5 . Patient 2 had dynamic spiral CT and patient 7 had Doppler of vertebral vessels.
The laboratory tests that were performed included complete blood count, sedimentation rate, biochemical and metabolic tests. Coagulation studies were performed in 6 patients including protein $\mathrm{C}$ and $\mathrm{S}$, antithrombin III and anticardiolipin antibodies. The remaining 3 patients ( 1,8 and 9 ) were not screened with these tests because the cause of the occlusion was clear. Virology studies for varicella were not done in any of the patients.

\section{Treatment}

Only 5 patients were treated with warfarin, while the remainder improved without any intervention. Patients 4 and 5 required surgery for recurrent vertebrobasilar episodes. The former patient had a right vertebral artery bypass and the latter fusion of the $C_{1} / C_{2}$ vertebrae.

\section{Results}

\section{Clinical Characteristics (table 1)}

Trauma varying from violent closed head injury to trivial neck manipulation occurred in 5 patients. It was due to neck twisting in patients 5 and 6 , nonaccidental injury in patient 1 and heavy tyres falling on the head in patient 9 . Foreign body embolism by a valve fragment was the cause in patient 8 , and rheumatic heart disease and possible encephalitis in patient 4 . The etiology was unknown in patients 2 and 7. All patients had sudden onset of symptoms. Hemiparesis with or without cranial nerve involvement occurred in 7 patients and ataxia was the main symptom in 2. While headache and neck pain are not consistent features in vertebrobasilar disease, headache was described in 4 patients of whom 2 also had neck pain. Disturbed sensorium or coma was documented in 5 patients. Afebrile seizures were reported in 1 patient and expressive aphasia in 2.

\section{Imaging Studies}

The CT scans of 8 patients were abnormal with low density lesions in the territory of the 
Table 1. Patient data of clinical features, artery involved, etiology and radiological study

\begin{tabular}{|c|c|c|c|c|c|c|c|c|c|}
\hline $\begin{array}{l}\text { Patient } \\
\text { No. }\end{array}$ & Age & Sex & Clinical features & Artery involved & Other & Etiology & Radiology study & $\begin{array}{l}\text { Treat- } \\
\text { ment }\end{array}$ & Follow-up \\
\hline 1 & 2 years & $\mathrm{F}$ & $\begin{array}{l}\text { coma, right hemiparesis, right } \\
\text { homonymous hemianopia }\end{array}$ & $\begin{array}{l}\text { left posterior } \\
\text { cerebellar artery }\end{array}$ & & $\begin{array}{l}\text { trauma, non- } \\
\text { accident injury }\end{array}$ & CT scan & no & $\begin{array}{l}\text { residual right } \\
\text { homonymous } \\
\text { hemianopia }\end{array}$ \\
\hline 2 & 11 years & $\mathrm{F}$ & $\begin{array}{l}\text { sudden-onset headache, ataxia, } \\
\text { double vision with left } 4 \text { th nerve } \\
\text { paresis }\end{array}$ & $\begin{array}{l}\text { right hemi } \\
\text { cerebellar synd. }\end{array}$ & & unknwon & $\begin{array}{l}\text { CT scan, MRI, } \\
\text { MRA }\end{array}$ & no & $\begin{array}{l}\text { complete neurological } \\
\text { recovery }\end{array}$ \\
\hline 3 & 18 months & $\mathrm{F}$ & $\begin{array}{l}\text { a febrile seizure, vomiting, coma, } \\
\text { retinal hemorrhages, ataxia }\end{array}$ & $\begin{array}{l}\text { right vertebral } \\
\text { artery }\end{array}$ & $\begin{array}{l}\text { right } \\
\text { PICA }\end{array}$ & ?trauma & $\begin{array}{l}\text { CT, dynamic spiral } \\
\text { CT, MRI, MRA }\end{array}$ & no & complete recovery \\
\hline 4 & 10 years & M & $\begin{array}{l}\text { sudden-onset headache, neck pain, } \\
\text { vomiting, drowsiness, left hemi- } \\
\text { paresis, left facial weakness, } \\
\text { dysarthria }\end{array}$ & $\begin{array}{l}\text { right vertebral } \\
\text { artery }\end{array}$ & $\begin{array}{l}\text { basilar } \\
\text { artery v. }\end{array}$ & $\begin{array}{l}\text { vasculitis, } \\
\text { ?encephalitis, } \\
\text { brain stem } \\
\text { dissection }\end{array}$ & $\begin{array}{l}\mathrm{CT}, \mathrm{MRI}, \\
\text { angiography }\end{array}$ & warfarin & $\begin{array}{l}\text { residual neurological } \\
\text { deficit }\end{array}$ \\
\hline 5 & 7 years & M & $\begin{array}{l}\text { headache, vertigo, ataxia, left } \\
\text { hemiparesis }\end{array}$ & $\begin{array}{l}\text { left vertebral } \\
\text { stenosis at } C_{2} \text {, } \\
\text { right posterior } \\
\text { cerebral artery } \\
\text { occlusion }\end{array}$ & & $\begin{array}{l}\text { twisting neck } \\
\text { trauma, embolism }\end{array}$ & CT, MRI, MRA & warfarin & $\begin{array}{l}\text { residual neurological } \\
\text { deficit, required } \\
\text { surgery fixation } C_{1} \\
\text { and } C_{2} \text { vertebrae }\end{array}$ \\
\hline 6 & 13 years & M & $\begin{array}{l}\text { sudden-onset left hemi-weakness, } \\
\text { left upper motor facial palsy, } \\
\text { dysarthria }\end{array}$ & basilar artery & & $\begin{array}{l}\text { neck } \\
\text { manipulation }\end{array}$ & CT, MRI, MRA & warfarin & $\begin{array}{l}\text { residual focal } \\
\text { neurological deficit }\end{array}$ \\
\hline 7 & 7 years & M & $\begin{array}{l}\text { headache, neck pain, sudden right } \\
\text { hemiparesis, right UMN facial palsy } \\
\text { expressive aphasia, depressed } \\
\text { consciousness }\end{array}$ & $\begin{array}{l}\text { left posterior } \\
\text { cerebral artery }\end{array}$ & & unknown & $\begin{array}{l}\text { CT, MRI, MRA, } \\
\text { Doppler of vertebral } \\
\text { vessels }\end{array}$ & warfarin & $\begin{array}{l}\text { residual focal } \\
\text { neurological deficit }\end{array}$ \\
\hline 8 & 15 years & M & $\begin{array}{l}\text { sudden right hemiplegia, hemi- } \\
\text { anesthesia, right facial palsy, right } \\
\text { homonymous hemianopia, } \\
\text { expressive aphasia }\end{array}$ & $\begin{array}{l}\text { left posterior } \\
\text { cerebral artery }\end{array}$ & & $\begin{array}{l}\text { rheumatic carditis, } \\
\text { foreign body } \\
\text { in PCA }\end{array}$ & $\mathrm{CT}$ & warfarin & $\begin{array}{l}\text { residual focal } \\
\text { neurological deficit }\end{array}$ \\
\hline 9 & 3 years & $\mathrm{M}$ & coma, left hemiparesis, ataxia & $\begin{array}{l}\text { right posterior } \\
\text { inferior cerebellar } \\
\text { artery }\end{array}$ & & trauma & $\mathrm{CT}, \mathrm{MRI}$ & no & complete recovery \\
\hline
\end{tabular}

$\mathrm{UMN}=$ Upper motor neurone; PICA = posterior inferior cerebellar artery; PCA = posterior cerebral artery. 


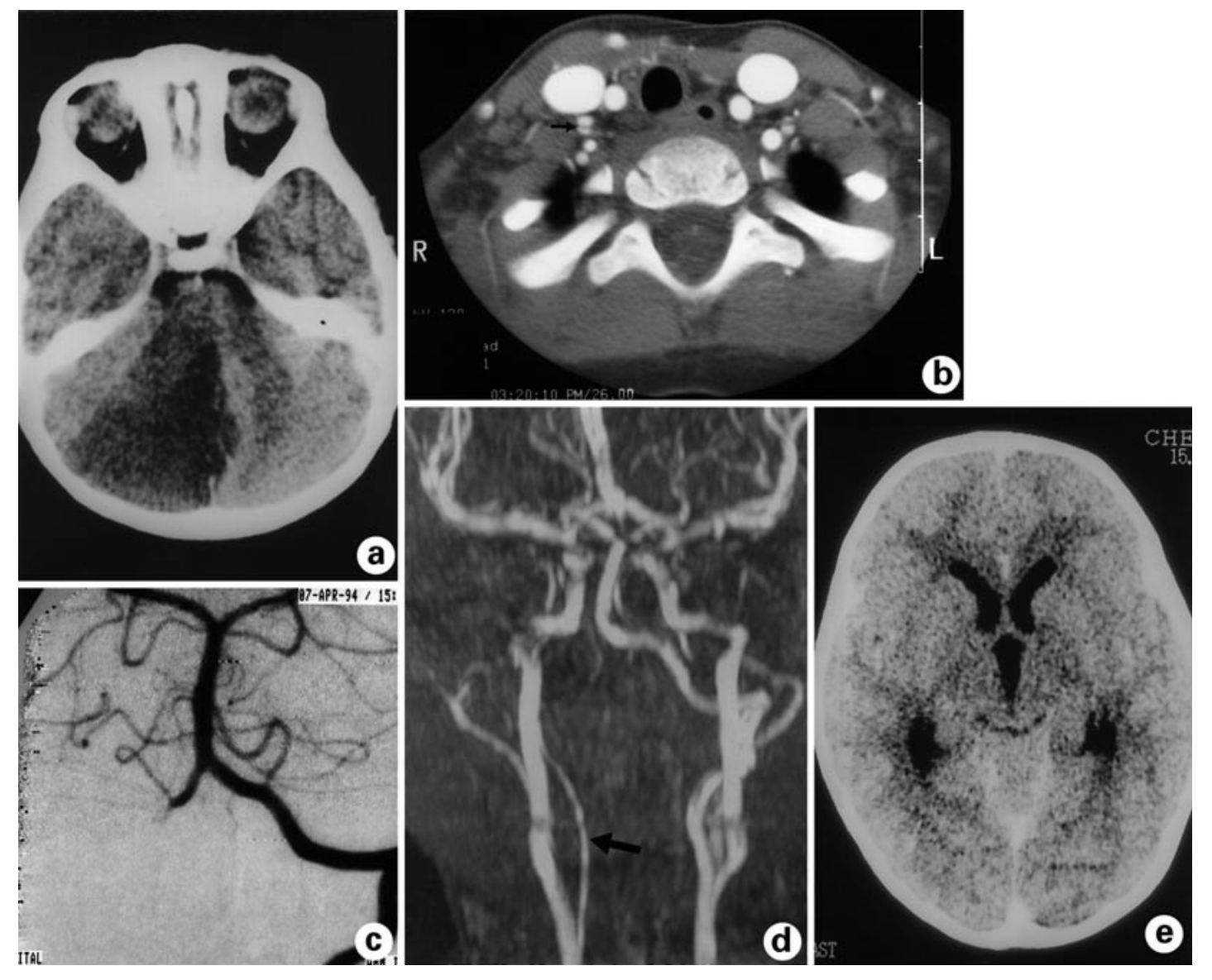

Fig. 1. a CT scan of recent infarct of mixed high and low density lesion in the right cerebellar hemisphere in the distribution of the right vertebrae artery. b Dynamic spiral CT demonstrating double lumen sign of dissection and intimal flap in right vertebral artery near its origin. c Formal angiogram consistent with complete obstruction of the right vertebral artery. d MRA demonstrating appearance of a small right vertebral artery consistent with recanalization. e T2 weighted image (MRI) of posterior cerebral artery.

occluded arteries. Patient 6 had normal initial CT image.

Seven patients had MRI. The study disclosed ischemic areas of low intensity signal on $\mathrm{T}_{1}$-weighted images and an intense signal suggesting edema on $\mathrm{T}_{2}$-weighted images in the territory of the vertebral artery for patients $3,4,5$ and 9 , and posterior cerebral artery or basilar artery territory in patients 2 , 6 and 7 (fig. 1a-e).

Vertebrobasilar Strokes in Children
MRA was performed for 3 patients. It was normal in patient 2 . The follow-up MRA for patient 3 done several months after the event revealed a right vertebral artery with small caliber due to recanalization. Patient 4 had recurrent transient ischemic attacks. Repeated angiographic studies disclosed slight irregularity of the basilar artery consistent with vasculitis, and on follow-up weeks later showed dissection of the right vertebral artery

Med Principles Pract 2000;9:186-193 189 
Fig. 2. a MRI. T2-weighted image demonstrating increased signal of thalamic infaction due to occlusion of posterior cerebral artery circulation. b Left vertebral artery angiogram demonstrating appearance consistent with occlusion at top of basilar artery; no filling of left posterior cerebral artery.
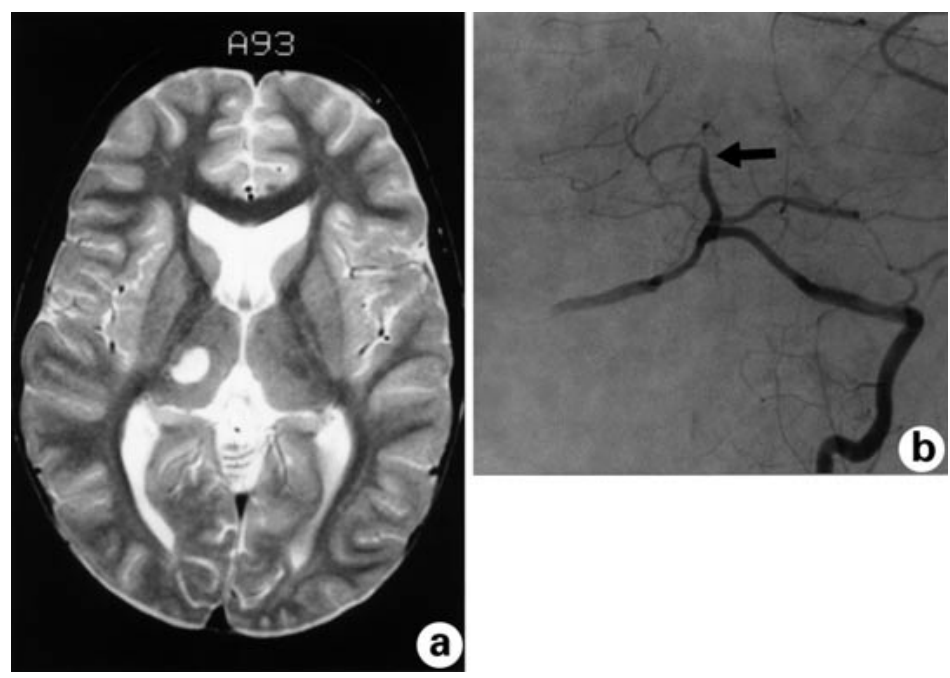

at the $\mathrm{C}_{2}$ level with subsequent embolization to the posterior circulation. Follow-up postoperative MRA done a year later demonstrated a small vertebral artery from the level of $C_{1}$ upwards and a patent anastomotic site. In patient 7 , afferent occlusion of the terminal basilar artery $3 \mathrm{~cm}$ from the bifurcation and of the left posterior cerebral artery at the level of the tectum was suggested by MRA, while the cerebral angiogram showed only a $0.5-\mathrm{cm}$ segment of basilar artery which was not filling (fig. 2a, b).

Conventional angiography confirmed the diagnosis in patients $3,4,5,6$ and 7 . In patient 3 , there was complete obstruction of the right vertebral artery between $C_{1}$ and the occiput secondary to dissection. Patient 5 had stenosis and intimal injury of the left vertebral artery at the $C_{1} / C_{2}$ junction with subsequent embolization of the posterior circulation. This patient had recurrent transient ischemic attacks, and on follow-up formal angiographic studies had complete stenosis of the vertebral artery with head rotation at $60^{\circ}$. Patient 6 showed complete obstruction of the basilar artery with the brain stem being supplied by collateral circulation.

\section{Laboratory Studies}

The coagulation studies did not reveal any prothrombotic disorders. None of the patients showed any evidence of homocystinemia.

\section{Outcome}

Acute hydrocephalus was documented as an early and late complication following vertebral artery occlusion in patients 3,5 and 9 . Complete neurological recovery was documented in patients 2, 3 and 9, while residual focal neurological deficits were reported in patients 1, 4, 5, 6, 7 and 8. Death occurred in patient 8 after 1 year due to intracranial hemorrhage secondary to a septic focus eroding the vessel wall at the site of the previously loaded foreign body. 


\section{Discussion}

The overall incidence of childhood stroke has been estimated at about 2.52-2.7 cases per 100,000 per year $[10,11]$. The incidence of strokes due to lesions in the vertebrobasilar arterial system in childhood is not known. From our experience, the proportion of childhood stroke due to vertebrobasilar disease was estimated at approximately one third of the total number of the study group.

Pediatric vertebrobasilar disease has received much more attention in the medical literature in recent years, yet it is considered a rare disease in the pediatric population. To the best of our knowledge, this is the largest series reported so far in childhood ( 3 females and 6 males). In this series, trauma was the main etiological factor in 5 patients, consistent with previous reports in which vertebral artery stroke was due to trauma [7, 12].

Patient 4 had probable brain stem encephalitis, and rubella infection was probably a risk factor. This patient had abnormal EEG with generalized slowing in the theta range and increased rubella IgM levels on ELISA, both of which returned to normal after 3 months. Viral infection is a risk factor for cerebrovascular ischemia [13] and is known to be associated with vascular inflammation [14]. Although foreign body embolism in the brain is rare, such an observation was made in patient 8 who had rheumatic carditis and embolization of a prosthetic mitral valve fragment in the left posterior cerebral artery. This observation probably supports the report [15, $16]$ that young adult males are affected more often and the right middle cerebral artery is the vessel occluded in the majority of patients. In 2 patients, the etiology was unknown.

Clinical onset in all patients was sudden and was followed by rapid progression. Frequent presenting features included hemipare- sis with cranial nerve involvement, ataxia and dysarthria. Headache and neck pain is not as consistent a feature as in adults. An atypical clinical presentation was observed in patient 3 with afebrile seizures and coma secondary to vertebral artery involvement. Ropper [17] described 8 adult patients with vertebrobasilar occlusive disease who had convulsive movements and suggested they were caused by ischemia of the spared corticospinal tract after the contralateral system had been infarcted [17].

A bilateral lesion of the pontine reticular formation generally causes coma. Bilateral lesions are typical of basilar artery stroke [18]. In the series of Garg et al. [6], coma occurred in cases with ischemic thalamic infarction due to occlusion in the thalamoperforate branch of the posterior cerebral artery. In the present series, suppressed sensorium or coma was the presenting feature of vertebral and posterior cerebral artery infarction as seen in patients 1 , $3,4,7$ and 9 . The maximal time to recover from coma was $48-72 \mathrm{~h}$ for patients 3 and 9 , the minimum of less than $24 \mathrm{~h}$ for patients 1 , 4 and 7.

Expressive aphasia is reported in adults following ischemic thalamic infarction [19, 20]. Garg et al. [6] described aphasia in a 14year-old male patient following a thalamotuberal infarct. In our series, patients 7 and 8 developed expressive aphasia with left posterior cerebral artery disease causing thalamic infarction. Homonymous hemianopia was observed in patients 1 and 8 with left posterior cerebral artery occlusion.

The posterior cerebral artery territory was involved in patients 1, 5, 6, 7 and 8. Thromboembolism from more proximal vascular disease was the precipitating pathology. In patient 8 , the cause was foreign body embolization of a prosthetic valve fragment. The vertebral artery at the $C_{1} / C_{2}$ level is most vulnerable to compression and stretching during 
head turning causing arterial spasm and transient interruption of blood flow related to head position. This was the case in patient 5 and required surgical fusion of the $C_{1} / C_{2}$ vertebrae. Kuether et al. [21] reported 3 adult patients with symptomatic dynamic changes in blood flow secondary to vertebral artery compression with rotational head motion [21]. The patients described by Garg et al. [6] illustrate vertebral artery intimal dissection related to trauma at the $\mathrm{C}_{1} / \mathrm{C}_{2}$ level with probable embolization in 3 patients [15].

In patient 2 the CT scan failed to identify the occluded artery. There was, however, a hypodense defect in the upper medial cerebellum. While MRI and MRA, which were done a few weeks later, displayed normal vertebrobasilar vessels, we believe this late timing of neuroimaging was an important factor in our failure to identify the involved artery. The earlier the study, the better the chances of visualizing the lesion.

Acute hydrocephalus was documented as an early and late complication in patients 3,5 and 9. Patient 3 developed transient hydrocephalus within $48 \mathrm{~h}$ related to the cerebellar edema associated with ischemia. Bergen et al. [1] reported acute hydrocephalus associated with cerebellum infarction due to vertebral artery occlusion in a child [1]. Acute hydrocephalus was documented in patient 5, 2 years following the vertebrobasilar strokes and was assumed to be due to the gliosis from previous infarctions interfering with cerebrospinal fluid circulation. In patient 9, there was associated brain contusion and edema following a closed head injury.

Aicardi [22] describes a guarded or poor prognosis if there is a detectable disorder of the brain vascular tree, e.g. from moyamoya disease or fibromuscular dysplasia, or if there is a recognizable underlying metabolic or general cause for occlusion, e.g. homoystinuria or vasculitis [22]. In the present series, 5 patients recovered with residual neurological deficits, 3 of them with posterior cerebral artery infarcts, 1 with basilar artery and 2 with vertebral artery involvement. The remaining 3 patients recovered completely.

Coagulation disorders were not seen in our patients with vertebrobasilar disease. The evaluation strategy and management should be organized in stages with each step influenced by the information from the history, physical examination and various hematological, biochemical, metabolic and neuroimaging procedures to identify the etiology and avoid the risk factors. Sudden presentation of a child with headache, vomiting, ataxia and focal neurological deficits should necessitate the use of MRI and MRA to identify the area infarcted and to disclose the involved artery. Whenever these tools are not available, CT scan should be carried out. Beside the routine tests, biochemical and infective causes including homocystinemia and varicella should be excluded. More recently described clotting defects, e.g. factor V Leiden mutation should be done.

Anticoagulant or antiplatelet treatment is highly controversial, especially in hemorrhagic infarct. Aspirin appears to be effective in reducing the relative risk of stroke and causes less bleeding complications than anticoagulant therapy [23].

\section{Conclusion}

This study confirms that vertebrobasilar disease is a rare disorder, and trauma is an important etiological factor in childhood. Knowledge of the cerebrovascular clinical syndromes will make it possible for the pediatrician to make a correct diagnosis rapidly and probably to suspect the cause of the disease.

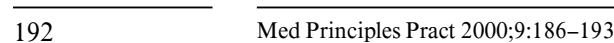

Al Tawari/Ouvrier/Steinberg/ Grattan-Smith/Antony 


\section{References}

1 Bergen BJ, Batnitzky S, Morantz RA, Price HI: Cerebellar infarction with associated acute hydrocephalus due to vertebral artery occlusion in a child. Neurosurgery 1981;8:383387.

2 Tekin S, Aykut-Bingol C, Sevinc A Case of intracranial vertebral artery dissection in young age. Pediatr Neurol 1997;16:67-70.

3 Horowitz IN, Niprako NA: Vertebral artery dissection with bilateral hemiparesis. Pediatr Neurol 1994; 11:252-254.

4 Zimmerman AW, Kumar AJ, Gadoth N, Hodges FJ: Traumatic vertebrobasilar occlusive disease in childhood. Neurol 1978;28:185-188.

5 Ishikawa T, Sasaki H, Makino K, et al: Pediatric brain stem infarction caused by a basilar and vertebral artery occlusion: Case report. Neurosurgery 1992;31:365-368.

6 Garg BP, DeMyer WE: Ischaemic thalamic infarction in children: Clinical presentation, etiology, and outcome. Pediatr Neurol 1995;13: 46-49.

7 Garg BP, Ottinger CJ, Smith RR, et al: Strokes in children due to vertebral artery trauma. Neurology 1993 ; 43:2555-2558.

8 Ouvrier RA, Hopkins IJ: Occlusive disease of the vertebrobasilar arterial system in childhood. Dev Med Child Neurol 1970;12:186-192.
9 North K, Kan A, de Silva M, Ouvrier R: Hemiplegia due to posterior cerebral artery occlusion. Stroke 1993;24:1757-1760.

10 Schoenberg BS, Mellinger JF, Schoenberg DG: Cerebrovascular disease in infants and children. A study of incidence, clinical features and survival. Neurology 1978;28: 763-768.

11 Broderick J, Talbot T, Preenger E, et al: Stroke in children within a major metropolitan area. J Child Neurol 1993;8:250-255.

12 Katiriji MB, Reinmuth OM, Latchaw RE: Stroke due to vertebral artery injury. Arch Neurol 1985;42: 242-248.

13 Grau AJ, Buggle F, Becher H, Zimmermann E, et al: Recent bacterial and viral infection is a risk factor for cerebrovascular ischemia. Neurol 1998;50:196-203.

14 Caekebeke JF, Peters AC, Vandvik $\mathrm{B}$, Brouwer OF, et al: Cerebral vasculopathy associated with primary varicella infection. Arch Neuro 1990;47:1033-1035.

15 Kase CS, White RL, Vinson TL, Eichelberger RP: Shotgun pellet embolus to the middle cerebral artery. Neurol 1981;31:458-461.
16 Vasik JM, Tew JM Jr: Foreign body embolization of the middle cerebral artery: Review of the literature and guidelines for management. Neurosurgery 1982;11:532-536.

17 Ropper AH: Convulsions in basilar artery occlusion. Neurology 1988; 38:1500-1501.

18 Roach ES, Riela AR: Syndromes of Vascular Dysfunction: Vertebrobasilar Syndromes: Pediatric Cerebrovascular Disorders. Mount Kisco, Futura Publishing, 1995.

19 Archer CR, Ilinsky IA, Goldfader PR, Smith KR Jr: Aphasia in thalamic stroke: CT stereotactic localization. J Comput Assist Tomogr 1981;5:427-432.

20 Gorelick PB, Heir DB, Benevento L, Levitt $S$, et al: Aphasia after left thalamic infarction. Arch Neurol 1984; 41:1296-1298.

21 Kuether TA, Nesbit GM, Clark WM, Barnwell SL: Rotational vertebral artery occlusion: A mechanism of vertebrobasilar insufficiency. Neurosurgery 1997;41:427-433.

22 Aicardi J: Cerebrovascular Disorders. Disease of the Nervous System in Childhood. New York, Raven Press, 1992.

23 The Stroke Prevention In Reversible Ischemia Trial (SPIRIT) Study Group: A randomized trial of anticoagulants versus aspirin after cerebral ischemia of presumed arterial origin. Ann Neurol 1997;42:857865 